\title{
Aplikasi Edukasi Pemecahan Masalah pada Vulnerability Server Berbasis Web
}

\author{
http://dx.doi.org/10.28932/jutisi.v7i1.3405 \\ Riwayat Artikel \\ Received: 15 Februari 2021 | Final Revision: 15 Maret 2021 | Accepted: 26 Maret 2021 \\ Achmad Syaichul Hadi ${ }^{\# 1}$, Mochamad Alfan Rosid ${ }^{\bigotimes \# 2}$ \\ "Program Studi Informatika, Universitas Muhammadiyah Sidoarjo \\ Jl. Mojopahit No.666 B, Sidowayah, Celep, Kec. Sidoarjo, Kabupaten Sidoarjo, Jawa Timur \\ ${ }^{1}$ saikulh@gmail.com \\ ªlfanrosideumsida.ac.id
}

\begin{abstract}
This research is purpose to design a virtual machine to simulate cyber attacks and find out how to design and build a virtual machine with a security gap that has been designed, so that it is used as education for web and server developers. The method used in building this system is the waterfall method which starts from designing a system to make it easier to build a system and then collecting data using observations to students of informatics engineering and computer engineering. The results of this system show that the system is able to run well, the guide for working on questions can be understood by the player, the player can inputs flags without problems, the clues provided are understandable and the educational videos provided are easy to understand. From the explanation aboce, the researchers concluded that this system can provide questions and education well.
\end{abstract}

Keywords - Education System; Server Weaknesses; Responsive Web; Laravel

\section{Pendahuluan}

Server adalah suatu sistem komputer yang memberikan layanan-layanan tertentu seperti sistem operasi, program aplikasi dan data-data informasi kepada komputer lain yang berhubungan dalam suatu jaringan komputer. Fungsi dari server adalah menyediakan suatu layanan kepada client, maka server dituntut untuk bisa mengerjakan semua permintaan client[1]. Penggunaan komputer sebagai server dalam suatu perusahaan atau instansi dilakukan sesuai kebutuhan dan fungsinya, seiring berjalannya waktu kebutuhan server bertambah banyak, sesuai dengan keperluan serta fungsi dari masing-masing server yang digunakan oleh perusahaan atau instansi tersebut, maka dari itu virtual machine dibuat untuk meminimalisir penggunaan server dengan perangkat keras, untuk beralih terhadap virtualisasi[2].

Selain itu ada serangan cyber pada jaringan yang dampaknya berbahaya dan dapat merusak data pada server, sehingga hal ini sangat merugikan pengguna. Di Indonesia masih menduduki peringkat pertama untuk kasus cyber crime. Dalam sebuah laporan "State of The Internet" yang dirilis Akamai pada kuartal II tahun 2013, Indonesia berada diposisi puncak sebagai negara dengan sumber serangan cyber crime dengan presentase 38\%, melampaui negara China yang berada di posisi kedua dengan presentase $33 \%$. Walaupun pemerintah Indonesia sudah mengupayakan pencegahan terhadap serangan cyber dengan membuat undang-undang, tindak kejahatan tetap saja masih banyak dan sulit di deteksi. Pada instansi pemerintahan masalah keamanan sistem (website atau server) tidak bisa disepelekan dan perlu diberikan sistem keamanan pada sebuah sistem (website atau server). Padahal sebuah website pemerintahan, seharusnya memberikan informasi yang valid dan mengamankan berbagai informasi yang bersifat privasi, seandainya ada penyusup yang mempunyai maksud jahat, penyusup tersebut bisa mengubah informasi yang ada pada sistem tersebut, tentu ini akan sangat membahayakan dan merugikan berbagai pihak. Di antara serangan cyber, Remote Code Execution (RCE) adalah salah satu ancaman yang paling berbahaya. Serangan ini memanfaatkan kelemahan aplikasi web untuk memasukkan dan mengeksekusi script dari sisi server yang berbahaya dalam konteks aplikasi yang ditargetkan. Akibatnya, penyerang bisa mendapatkan akses ke server dan dapat merugikan pemilik server, salah satu metode pengujian keeamanan pada sistem yang dapat dilakukan yaitu dengan menggunakan penetration testing. Pengertian dari penetration testing sendiri adalah sebuah metode pengujian keamanan sistem dengan cara mensimulasikan serangan-serangan yang mungkin bisa dilakukan pada suatu sistem agar mengetahui celah keamanan pada sistem[3][4].

Maka dari itu perlu adanya sebuah edukasi bagaimana menambal atau mencegah serangan-serangan cyber pada suatu sistem. Pengertian dari edukasi yaitu sebuah proses yang dilakukan oleh seseorang, untuk menemukan jati dirinya dengan mengamati dan belajar yang kemudian melahirkan tindakan dan prilaku, sedangkan kata edukasi 
berasal dari bahasa Inggris yaitu education yang berarti pendidikan[5][6].

Permasalahan yang menjadi topik utama penelitian ini adalah sebagai berikut. Bagaimana mengetahui dan cara meminimalisir serangan cyber itu terjadi pada server. Penelitian ini dilakukan dengan tujuan untuk merancang bangun mesin virtual untuk simulasi serangan cyber dan smengetahui cara merancang dan membuat mesin virtual dengan celah keamanan yang sudah dirancang, sehingga dijadikan edukasi kepada pihak pengembang web dan server.

\section{KAJIAN TEORI}

Penelitian yang pertama dilakukan oleh Keerthika.T dan Adithyan.A dengan judul "Remote Code Execution in Web Applications" dalam pengujian ini peniliti menganalisa pada sebuah aplikasi yang dimana celah keamanan RCE itu berjalan. RCE berjalan melalui path pada sebuah script yang terdapat sebuah fungsi yang bisa melakukan eksekusi script dari sisi server yang menyebabkan penyerang bisa mendapatkan akses ke sumber daya (server) pada aplikasi tersebut. Hasil yang didapat adalah Pemasangan Intrusion Detection System (IDS) adalah tindakan yang disarankan untuk mengurangi serangan ini. Pada era digital, di mana kita harus menjaga privasi kita sendiri serta data pribadi, cara terbaik untuk mengurangi jenis serangan ini adalah dengan menjalankan program bug bounty melalui platform seperti HackerOne dan BugCrowd, dengan mengundang hacker untuk tampil uji penetrasi pada aplikasi, anda dapat mengetahui tentang level keamanan sistem dari sudut pandang hacker [4].

Penelitian yang kedua dilakukan oleh Naufal Arkaan dan Dolly Virgian Shaka Yudha Sakti dengan judul "Implementasi Low Interaction Honeypot Untuk Peningkatan Keamanan Server dan Analisa Serangan pada Protokol SSH". Tujuan dari penelitian ini adalah melakukan implementasi pada server menggunakan aplikasi honeypot low interaction dan juga menganalisa serangan pada port $\mathrm{SSH}$, aplikasi honeypot ini nantinya dapat menyembunyikan service port SSH yang asli, hanya bisa diakses dan diserang oleh penyerang serta membuat service port SSH palsu yang menipu dan memantau si penyerang dalam melakukan serangan terhadap server. Honeypot sendiri memiliki 2 interaksi honeypot low interaction dan honeypot high interaction, penelitian ini menggunakan honeypot low interaction dikarenakan memberikan pengalaman yang baik bagi yang belum berpengalaman dan masih dalam tahap pembelajaran membangun honeypot dan menganalisa perilaku apa yang dilakukan penyerang di dalam server dan juga kemungkinan cara kredensial masuk ke dalam server yang digunakan oleh penyerang, dengan begitu hasil dari serangan dapat dipelajari untuk administrator sistem untuk membuat server menjadi aman. Dan hasil penelitian bahwa honeypot yang dibuat menggunakan $\mathrm{SSH}$ server palsu atau SSH tiruan yang untuk mengelabui penyerang sehingga penyerang tidak menyerang SSH server yang asli, dan honeypot yang dibuat membantu meningkatkan keamanan pada server[7].

Penelitian yang dilakukan Erri Wahyu Puspitarini dan Dian Wahyu Putra dengan judul "Game Edukasi Berbasis Android Sebagai Media". Penelitian ini membahas merancang bangun game edukasi yang berbasis android. Dan hasil dari penelitian ini dibuat sebuah game edukasi berbasis sistem operasi Android yang ditujukan dan dapat digunakan untuk pembelajaran anak usia dini serta mengajarkan tentang pengembangan daya pikir dan daya cipta yang meliputi pembelajaran mengenal binatang, lagu-lagu anak, coret ceria, mewarnai, dan alphabet serta didukung dengan antarmuka yang mudah dimengerti dan dioperasikan oleh anak usia dini 3-6 tahun[6].

\section{A. Mesin Virtual}

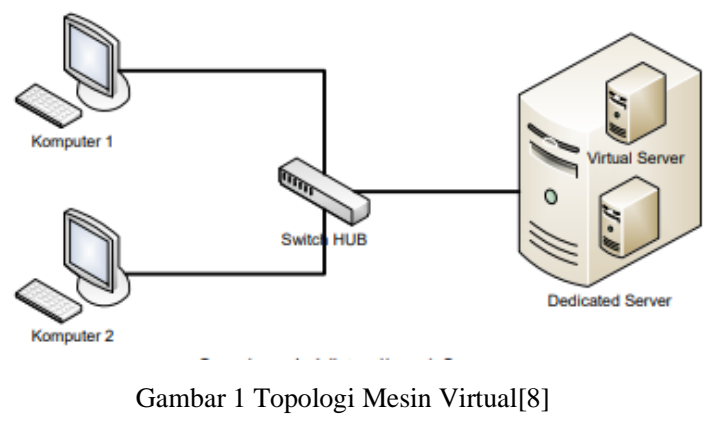

Mesin virtual adalah program sistem komputer yang bisa menjalankan banyak sistem operasi diatas sistem operasi lain dan bisa menjalankan aplikasi untuk sistem operasi lainnya. Gambar 1 menunjukkan server virtual dibangun didalam server dedicated, jika dilihat dari bentuk fisiknya, hanya berupa satu buah server. Server tersebut didalamnya terdapat virtual server yang tentunya, perancangan dan pembangunannya disesuaikan dengan kebutuhan dari sistem yang akan diimplimentasikan yaitu dua sistem dengan dua operating sistem yang berbeda. Virtual machine akan membuat suatu sistem virtual yang nantinya dapat dipasang sebuah sistem operasi yang tidak saling terhubung dengan sistem operasi utama[2].

Terdapat beberapa software virtual machine, salah satunya virtualbox. VirtualBox merupakan solusi virtualisasi populer untuk penggunaan perusahaan dan pribadi. Selain itu, ini didistribusikan tanpa biaya di bawah persyaratan versi 2 dari Lisensi Publik Umum GNU (GPL v2), juga tersedia untuk platform 32 dan 64-bit. VirtualBox saat ini dapat menjalankan banyak jenis sistem operasi seperti Linux, Windows, Macintosh dan Solaris. Menginstall dan VirtualBox dapat menjalankan beberapa mesin virtual di atasnya masing-masing dengan sistem operasi sendiri, sambil berbagi sumber daya fisik yang disediakan oleh perangkat keras yang mendasarinya[9]. 


\section{B. Server}

Server adalah suatu sistem komputer yang memberikan layanan-layanan tertentu seperti sistem operasi, program aplikasi dan data-data informasi kepada komputer lain yang berhubungan dalam suatu jaringan komputer. Fungsi dari server adalah menyediakan suatu layanan kepada client, maka server dituntut untuk bisa mengerjakan semua permintaan client [1].

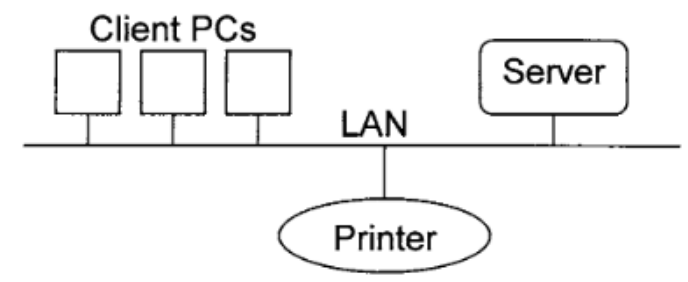

Gambar 2 Topologi server[10]

Server juga sebagai sistem atau program yang menerima permintaan dari satu atau lebih sistem atau program klien untuk melakukan aktivitas yang memungkinkan klien menyelesaikan tugas tertentu. Gambar 2 menunjukkan jaringan area typical local jaringan berdasarkan teknologi client/server. Konsep client/server secara fungsional membagi pelaksanaan unit kerja antara aktivitas yang dilakukan oleh pengguna akhir (client) dan respons sumber daya (service) ke permintaan aktivitas[10].

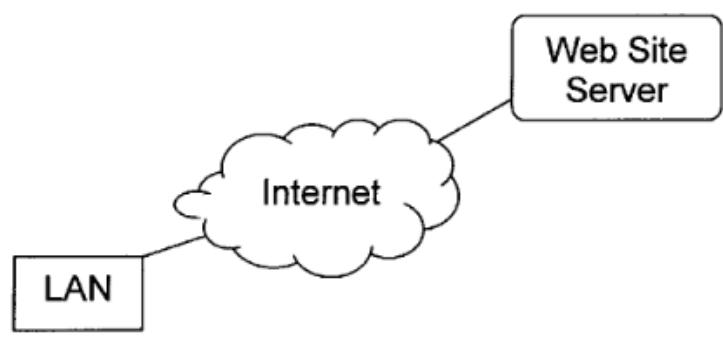

Gambar 3 Topologi LAN terhubung ke Web Site Server[10]

Pada 1980-an, ketika PC pertama kali diperkenalkan secara komersial, sistem file ada di PC itu sendiri. Jaringan Area Lokal (LAN) menyediakan akses ke sistem file di server lokal, dan dengan interkoneksi menggunakan LAN akses tersebut telah diperluas ke server jarak jauh di jaringan perusahaan dan Web. Gambar 3 menunjukkan bagaimana klien di LAN dapat mengakses server host web jarak jauh melalui Internet[10].

\section{IP Address}

Kegunaan IP Address adalah untuk mengidentifikasi interface pada host dari suatu mesin atau suatu perangkat. Penjelasan dari ip address adalah sekelompok bilangan biner dengan ukuran 32 bit yang dibagi menjadi 4 bagian yang masing-masing bagian itu terdiri dari 8 bit. Untuk memudahkan manusia dalam membaca suatu alamat IP, maka pada umumnya penamaan yang digunakan adalah bilangan decimal, berikut aturan pemakaian ip address pada Table I[2].

TABEL I

KELAS IP ADDRESS

\begin{tabular}{|l|l|l|l|l|}
\hline $\begin{array}{c}\text { Kelas } \\
\text { IP }\end{array}$ & $\begin{array}{c}\text { Alamat } \\
\text { IP }\end{array}$ & \multicolumn{1}{|c|}{ Subnet } & $\begin{array}{c}\text { Jumlah } \\
\text { Network } \\
\text { ID }\end{array}$ & $\begin{array}{c}\text { Jumlah } \\
\text { Host ID }\end{array}$ \\
\hline A & $1-126$ & $\begin{array}{l}255 . X X X . X X \\
\text { X.XXX }\end{array}$ & 126 & $\begin{array}{l}1677721 \\
4\end{array}$ \\
\hline B & $127-191$ & $\begin{array}{l}255.255 . X X X \\
\text { XXX }\end{array}$ & 16384 & 65534 \\
\hline C & $192-254$ & $\begin{array}{l}255.255 .255 . X \\
\text { XX }\end{array}$ & 2097152 & 254 \\
\hline
\end{tabular}

Tujuan dari TCP/IP adalah membangun suatu koneksi antar jaringan atau biasa disebut network, yang menyediakan pelayanan komunikasi antar jaringan yang memiliki bentuk fisik yang beragam. Tujuan yang jelas dari TCP/IP adalah menghubungkan hosts pada jaringan yang berbeda. IP memiliki aspek penting yaitu membentuk suatu standarisasi dalam melakukan sebuah komunikasi. Setiap bentuk fisik suatu jaringan memiliki teknologi yang berbeda-beda, sehingga diperlukan pemrograman atau fungsi khusus untuk dipakai dalam sebuah komunikasi. IP memberikan fitur khusus yang berjalan diatas pemrograman atau fungsi khusus tersebut dari masing-masing setiap fisik jaringan, sehingga bentuk arsitektur dari fisik jaringan akan tersamarkan dari pengguna dan pembuat aplikasi jaringan, maka pengguna tidak perlu lagi memikirkan bentuk fisik jaringan untuk melakukan sebuah komunikasi[11].

\section{Ubuntu Server}

Linux pertama kali dikembangkan oleh Linus Benedict Torvalds. Semua kode dan package dari Linux disebarkan secara opensource dengan lisensi GPL (General Public License) versi kedua. Selain itu linux mempunyai beberapa distro, antara lain :

a. Debian seperti Knoppix, Ubuntu, dan lain-lain.

b. RPM (RedHat Package Manager) seperti FedoraCore, IGOS, CentOS, dan lain-lain.

c. Slackware seperti Slackware, Kate OS, Truva Linux, dan lain-lain.

Berdasarkan keterangan diatas, ubuntu adalah salah satu distribusi Linux yang berbasiskan Debian dan memiliki tampilan GUI (Graphical User Interface) yang bagus. Nama Ubuntu sendiri diambil dari bahasa kuno Afrika Zulu dan Xhosa (oo-boon-too) yang artinya "rasa perikemanusiaan terhadap orang lain". Dijelaskan juga bahwa desktop bawaan Ubuntu adalah Gnome, Gnome merupakan platform pengembangan dan keluarga desktop UNIX dan Linux terkenal. Ubuntu juga memiliki skema penomoran versi berdasarkan pada tanggal rilis sebuah versi dari distribusi. Ubuntu juga mempunyai nomor versi berasal dari tahun dan bulan rilis[12]. 


\section{E. Laravel}

Laravel adalah framework PHP Open Source yang dibuat oleh Taylor Otwell di bawah lisensi MIT. Laravel dibuat untuk membantu para developer dalam membuat sebuah web dengan sintaks yang sederhana, elegan, ekspresif, dan menyenangkan, dengan menggunakan laravel, tugas-tugas umum developer dapat dikurangi pada sebagian besar proyek-proyek web seperti routing, session dan caching. Laravel berusaha menggabungkan pengalaman pengalaman development dalam Bahasa lain, seperti Ruby on Rails, ASP.NET, MVC dan Sinatra. Tujuan utama dibuatnya laravel adalah mempermudah developer dalam melakukan coding untuk sebuah produk web[13].

PHP (Hypertext PreProcessor) adalah bahasa pemrograman yang digunakan untuk mengolah data dari server untuk ditampilkan di website. PHP digunakan untuk membuat website dinamis. Dalam penggunaannya, kodekode PHP disisipkan diantara kode HTML. Secara default, dokumen PHP yang memiliki ekstensi .php, saat server web menemukan file dengan jenis ini, file tersebut otomatis dikirim untuk diproses oleh server[13].

\section{F. Bootstrap}

Bootstrap adalah framework frontend paling populer yang dibuat untuk merancang antarmuka yang elegan, kuat, dan responsif untuk halaman web tingkat professional. Bootstrap menggunakan komponen-komponen HTML, CSS, dan Javascript, bootstrap dibuat oleh Mark Otto dan Jacob Thornton dari Twitter dan diluncurkan sebagai produk open source atau gratis pada Agustus 2011. Bootstrap menyediakan fitur komponen tampilan yang bagus seperti Typography, Forms, Buttons, Tables, Navigations, Dropdowns, Alerts, Modals, Tabs, Accordion, Carousel, dan lain lain. Berikut Kelebihan Bootstrap :

a. Menghemat waktu, dengan menggunakan berbagai desain template dan kelas yang sudah ada dalam Bootstrap.

b. Responsive, bootstrap memiliki desain yang responsive, dengan fitur fitur yang disediakan oleh bootstrap tanpa perlu adanya perubahan kode.

c. Desain konsisten, komponen pada bootstrap mempunyai template dan style yang sama sehingga membuat tampilan web menjadi konsisten. d. Mudah digunakan dan didukung oleh semua browser, bootstrap hanya perlu pengetahuan dasar HTML, JS, dan CSS. Bootstrap dapat digunakan pada semua browser[14].

\section{G. Mysql}

MySQL merupakan perangkat lunak sistem manajemen basis data SQL atau DBMS yang multithread, multi-user. MySQL tersedia dengan gratis di bawah lisensi GNU (GPL), tetapi mereka juga menjual lisensi berbayar jika penggunanya tidak cocok dengan penggunaan GPL. MySQL merupakan perangkat lunak database open source yang paling populer di dunia, dimana saat ini digunakan lebih dari 100 juta pengguna di seluruh dunia. Kelebihan dari MySQL adalah kehandalan, kecepatan dan kemudahan penggunaannya, MySQL menjadi pilihan utama bagi pengembang software dan aplikasi pada platform web maupun desktop. Pengguna MySQL tidak hanya sebatas pengguna perseorangan maupun perusahaan kecil, namun perusahaan besar juga merupakan pengguna dari MySQL. MySQL pertama kali dibuat dan dikembangkan di Swedia oleh David Axmark, Allan Larsson dan Michael "Monty" Widenius. Mereka mengembangkan MySQL sejak tahun 1980-an. Saat ini versi MySQL yang sudah stabil mencapai versi 5x, dan sedang dikembangkan versi 6x.[15].

\section{ANALISIS DAN RANCANGAN SISTEM}

\section{A. Diagram Usecase}

Penjelasan dari Gambar 4 yaitu pertama user melakukan connect ke mesin virtual (server) dengan mencari ip dari server tersebut setelah menemukan alamat ip, setelah itu melakukan scanning pada port service server untuk selanjutnya mencari sebuah celah kemanan pada service tersebut. Selanjutnya user melakukan exploit pada celah keamanan tersebut. Pada proses ini user mencari jawaban (flag) pada celah tersebut, yang nantinya digunakan untuk menjawab pada soal yang disediakan pada web. Selanjutnya jika sudah menemukan flag, user melakukan login pada sistem web edukasi, jika nanti user mengalami kesusahan dalam mengerjakan soal, terdapat sebuah petunjuk untuk membantu mencari flag. Selanjutnya user mengisi jawaban pada kolom yang sudah disediakan dengan flag, setelah jawaban user benar, user mendapatkan edukasi untuk memperbaiki celah keamanan pada server tersebut. 


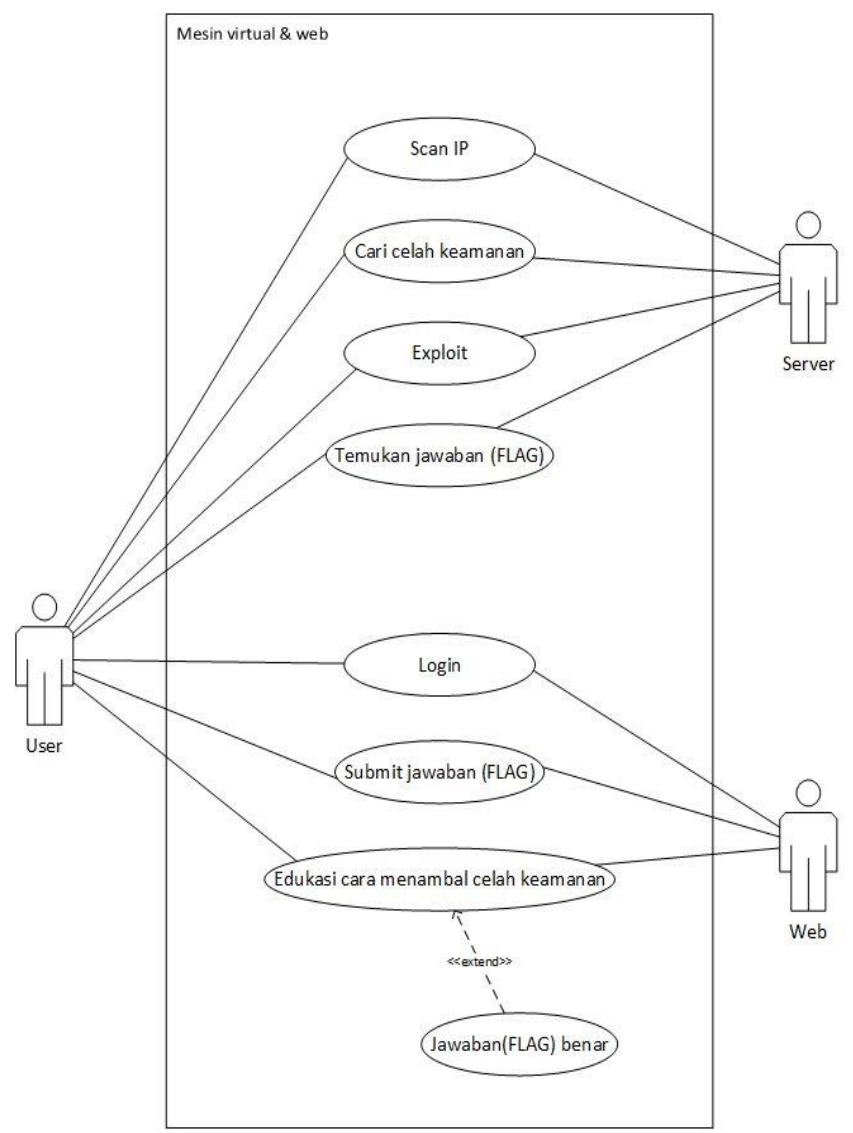

Gambar 4 Diagram usecase Aplikasi Edukasi Pemecahan Masalah Pada Vulnerability Server Berbasis Web

\section{B. Flowchart}

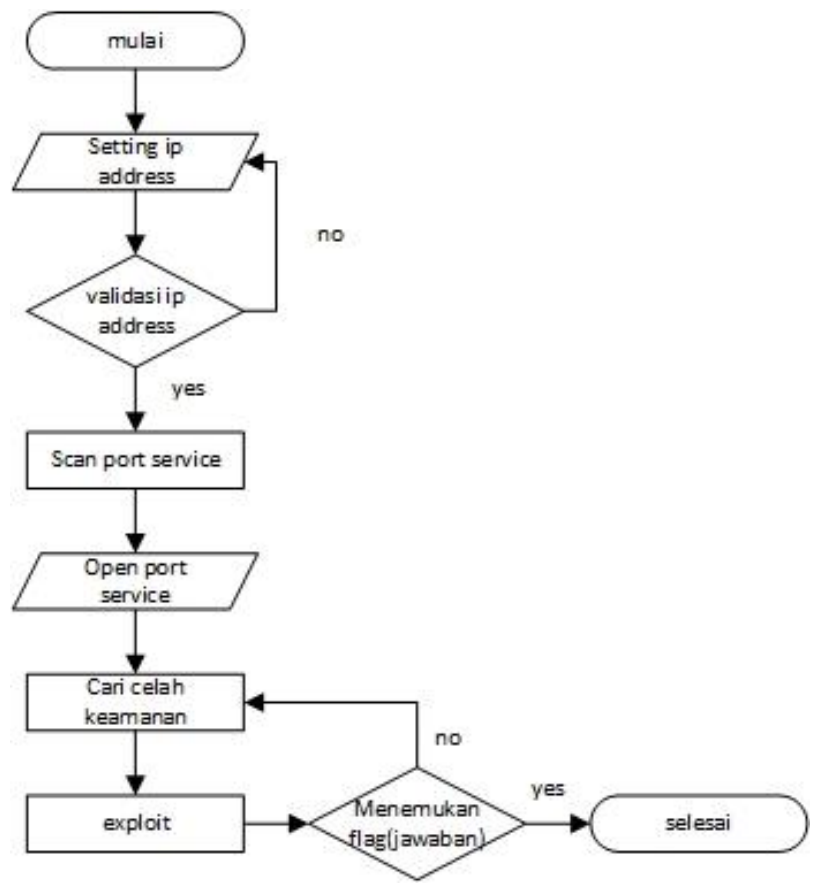

Gambar 5 Flowchart mesin virtual
Penjelasan dari Gambar 5 yaitu pertama user melakukan setting pada ip address untuk mengakses pada mesin virtual (server) jika sudah user akan di cek terlebih dahulu apakah ip address yang digunakan valid apa tidak, kalau tidak otomatis tidak bisa mengakses server. Selanjutnya user melakukan scanning port service kepada server menggunakan aplikasi nmap. Pada proses ini user akan menemukan port service terbuka pada server, lalu user akan mencari celah keamanan pada setiap port dan melakukan exploit terhadap mesin virtual. Selanjutnya mencari dimana jawaban (flag), jika tidak ditemukan maka dilakukan pencarian ulang, setelah menemukan jawaban(flag), user akan memasukkan jawaban(flag) ke dalam sistem web yang sudah disediakan. 


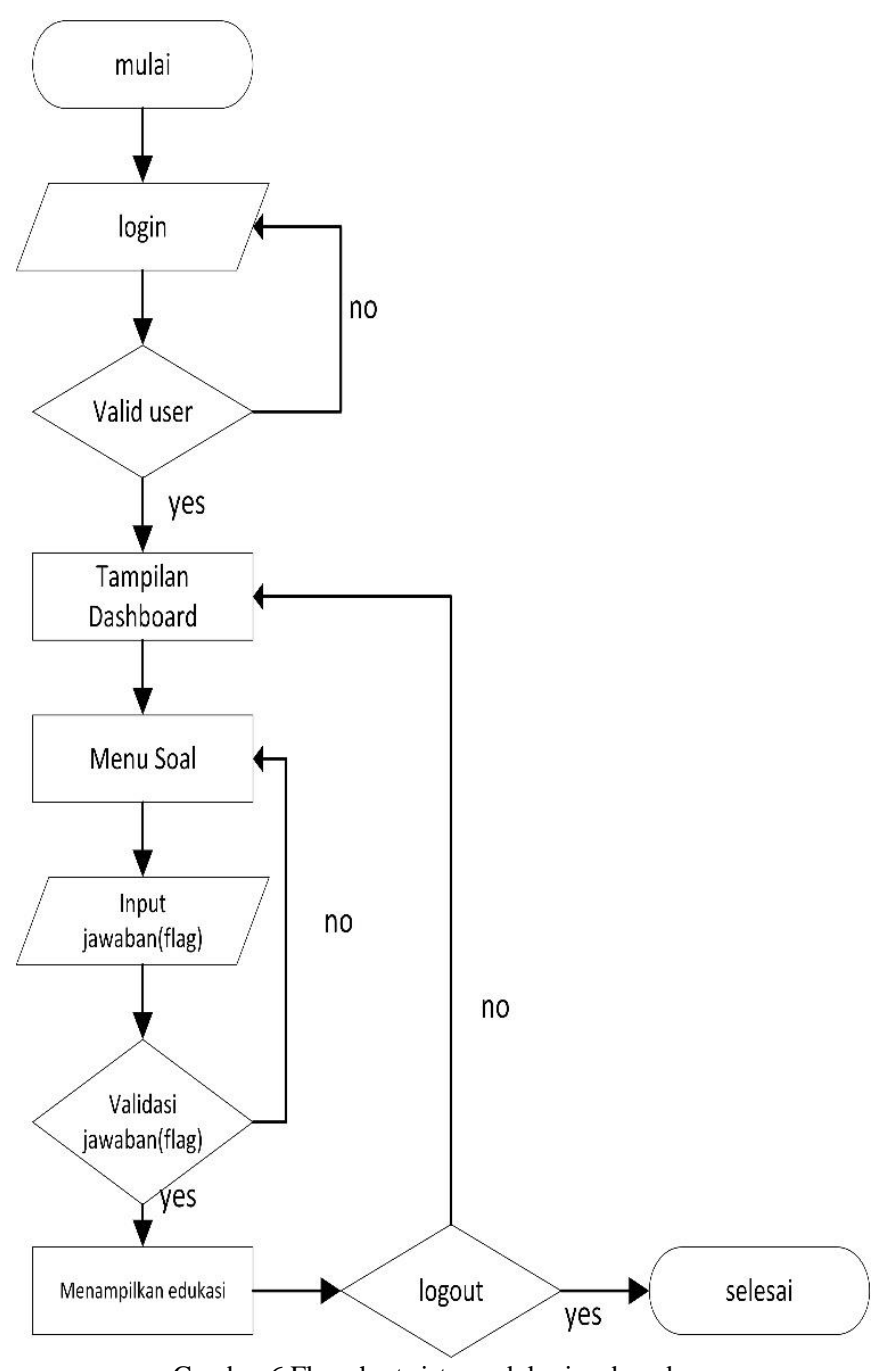

Gambar 6 Flowchart sistem edukasi web pada $u$ ser

Penjelasan dari Gambar 6 yaitu user melakukan login terlebih dahulu, kalau user benar maka akan menampilkan tampilan halaman utama (dashboard), selanjutnya user akan diarahkan ke menu soal, Pada proses selanjutnya user memasukkan jawaban (flag) yang sudah didapatkan pada mesin virtual ke kolom jawaban, selanjutnya dilakukan validasi pada jawaban, jika salah user akan diarahkan ke halaman menu soal. Selanjutnya jika jawaban sudah benar user akan menampilkan edukasi untuk memperbaiki celah keamanan pada soal tersebut, selanjutnya user bisa melakukan logout.

Penjelasan pada Gambar 7 yaitu melakukan login terlebih dahulu, jika valid maka akan diarahkan ke tampilan dashboard, selanjutnya admin akan membuat soal pada menu soal, yang nantinya kategori soal ada : server dan web. Setelah proses pembuatan soal selesai, admin akan melakukan logout.

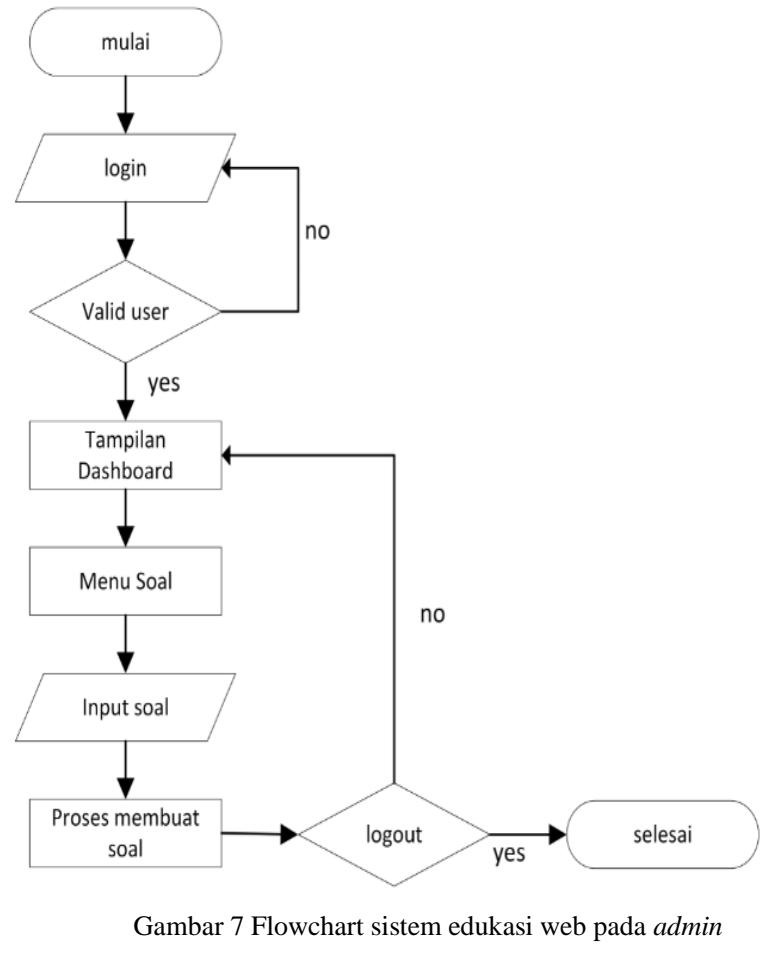

\section{Diagram Konteks}

Diagram konteks adalah diagram secara global dari sebuah sistem informasi yang menggambarkan aliran-aliran data ke dalam dan ke luar dari dalam dan luar entitas eksternal.

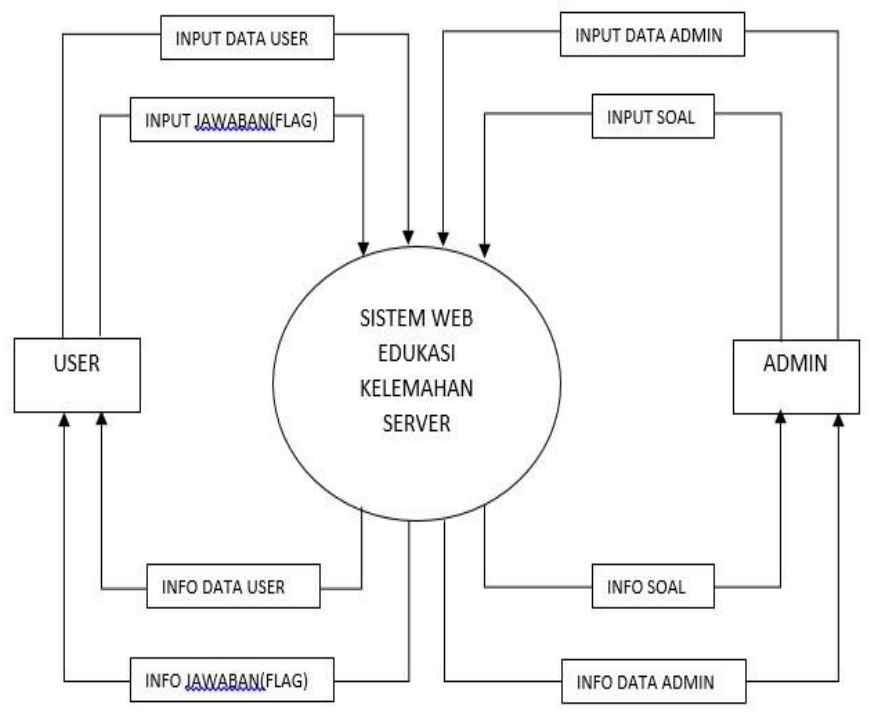

Gambar 8 Diagram Konteks pada sistem edukasi web

Penjelasan Gambar 8 yaitu ada 2 user atau bisa difungsikan sebagai user biasa dan admin sebagai level user tertinggi. User dapat melakukan input data user yang diantaranya untuk melakukan login dan dapat memperoleh info data user untuk melihat data diri user. User juga dapat melakukan input jawaban pada sistem untuk melakukan submit jawaban dan user memperoleh info jawaban untuk 
melihat jawaban yang di masukkan itu benar apa salah. Sedangkan untuk admin bisa melakukan input data soal, dan mendapatkan info soal jika pembuatan soal sudah berhasil apa tidak, admin juga dapat melakukan login yang sama seperti user.

\section{Data Flow Diagram (DFD)}

DFD adalah sebuah teknik yang menggambarkan aliran data atau informasi yang digunakan. DFD dibuat dengan tujuan untuk memperjelas arus data pada sistem dengan struktur yang jelas.

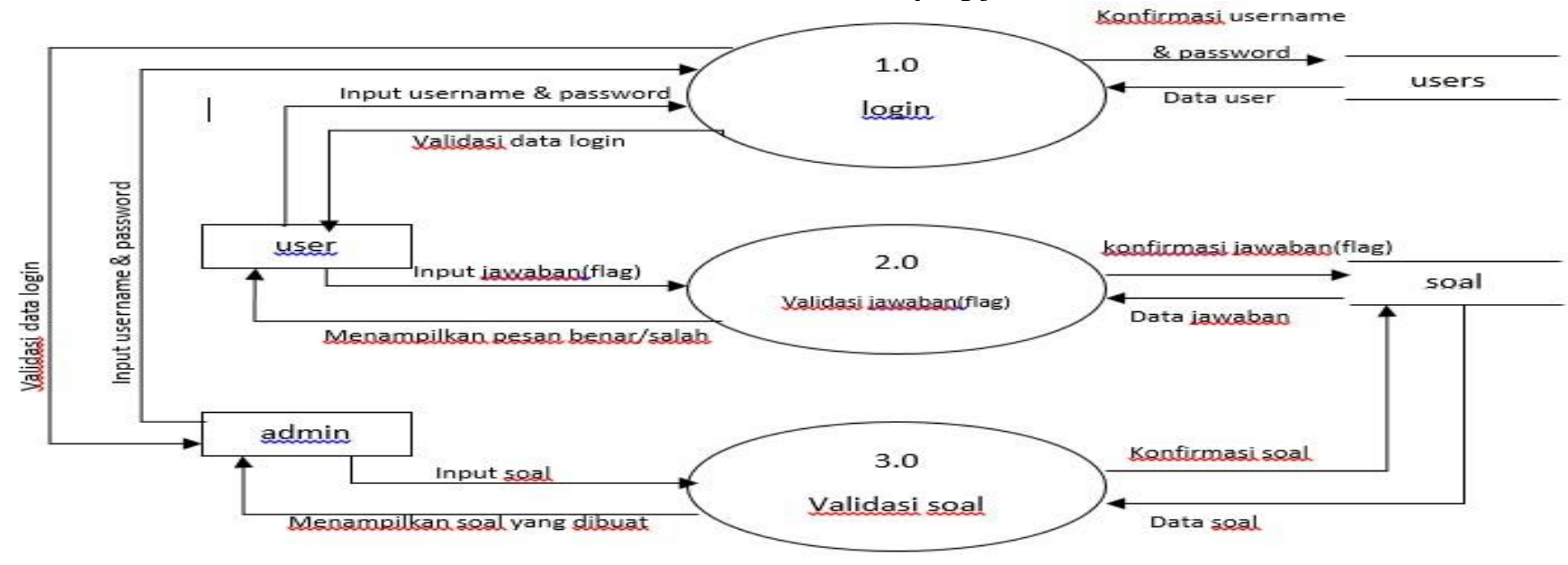

Gambar 9 DFD pada sistem edukasi web

Penjelasan Gambar 9 yaitu ada 2 user atau bisa difungsikan sebagai user biasa dan admin sebagai level user tertinggi. User melakukan input username \& password agar bisa masuk ke dalam sistem edukasi web. Data user dikoneksikan ke dalam database users dan dikonfirmasi untuk melakukan validasi bahwa data user memang ada. Selanjutnya user melakukan input jawaban agar bisa mendapatkan edukasi untuk memperbaiki celah keamanan, sebelumnya dilakukan validasi jawaban terlebih dahulu terhadap data ke dalam database soal. Admin juga melakukan input username \& password agar bisa masuk ke dalam sistem edukasi web. Data admin dikoneksikan ke dalam database users dan dikonfirmasi untuk melakukan validasi bahwa data admin memang ada. Selanjutnya admin melakukan input soal yang nantinya dilakukan validasi pada soal terhadap data kedalam database soal, proses ini admin akan membuat soal untuk dikerjakan oleh user.

\section{E. Entity Relationship Diagram (ERD)}

ERD adalah model himpunan entitas yang memiliki atribut - atribut dan dilengkapi dengan hubungan antar entitasnya.

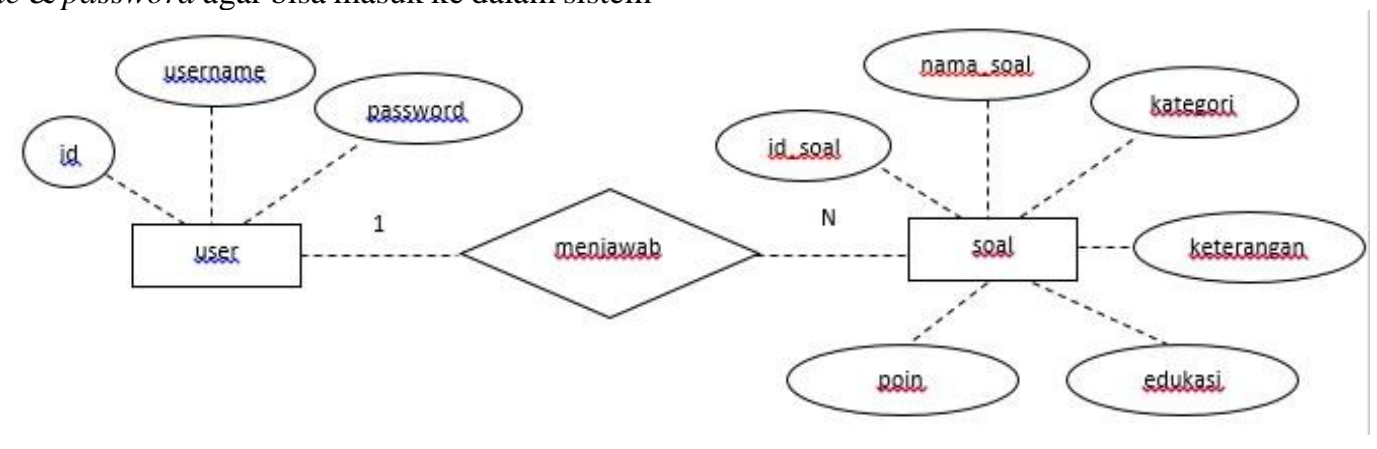

Gambar 10 ERD pada sistem edukasi web pada $u$ ser

Penjelasan dari Gambar 10 yaitu entitas user memiliki atribut id, username, dan password. Dan entitas soal memiliki atribut id_soal, nama_soal, kategori, keterangan, edukasi dan poin. Dua entitas diatas saling berhubungan yang artinya user dapat menjawab soal. 


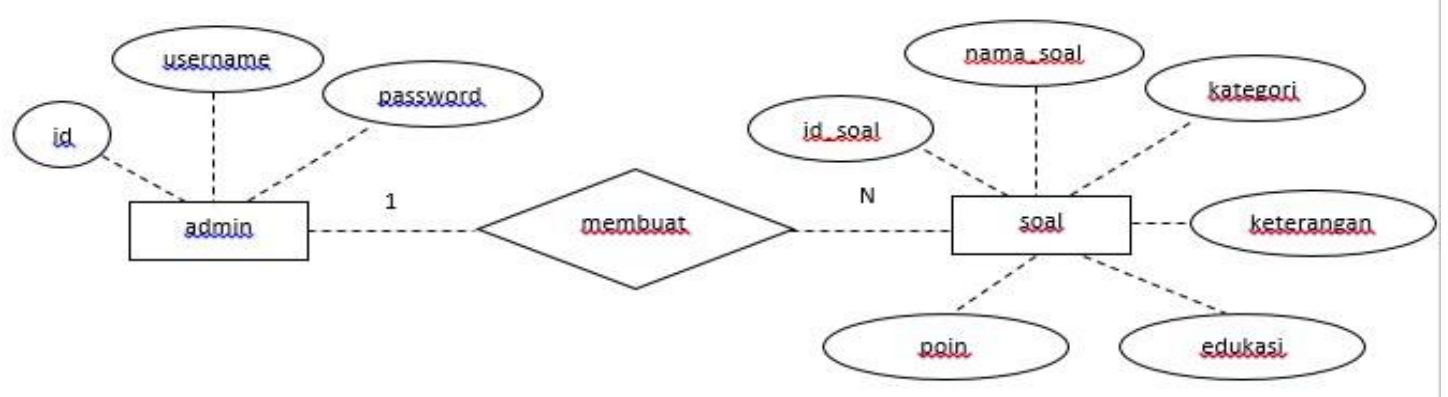

Gambar 11 ERD pada sistem edukasi web pada admin

Penjelasan dari Gambar 11 yaitu entitas admin memiliki atribut id, username, dan password. Dan entitas soal memiliki atribut id_soal, nama_soal, kategori, keterangan, edukasi dan poin. Dua entitas diatas saling berhubungan yang artinya user dapat membuat soal.

\section{F. User Interface}

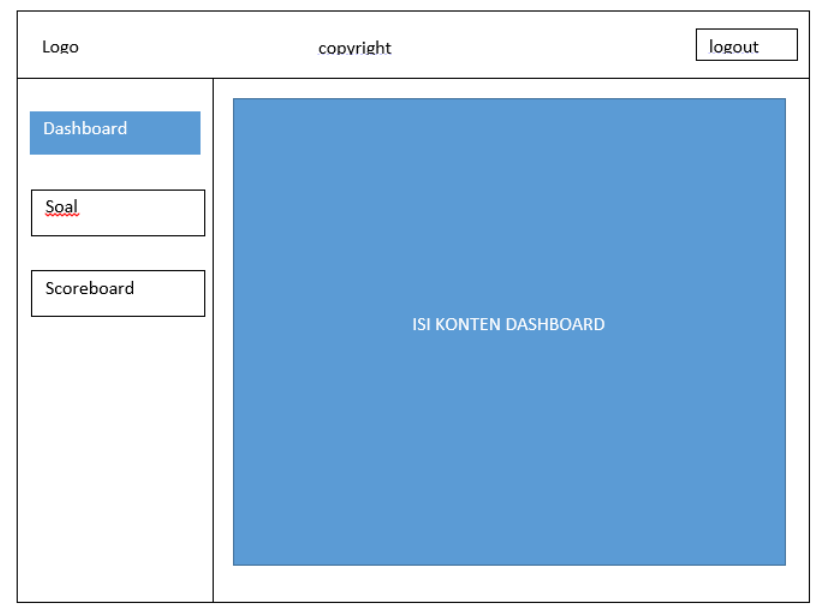

Gambar 12 Tampilan Dashboard User

Penjelasan dari Gambar 12 yaitu skema tampilan sistem web pada bagian user, terdapat logo yang nantinya akan dibuat untuk tombol home. Sedangkan untuk copyright, dibuat label copyright pada web. Terdapat juga tombol logout untuk user melakukan keluar pada sistem web. Fitur tombol dashboard nanti akan menampilkan konten yang terdapat pada dashboard.

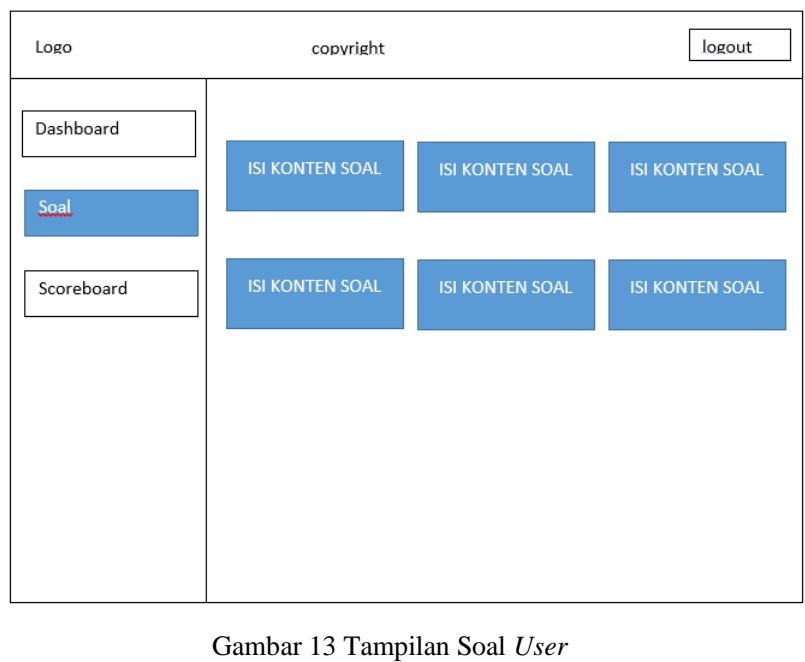

Penjelasan dari Gambar 13 yaitu skema pada tampilan soal pada user, yang isinya soal-soal untuk dijawab oleh user, dimana saat user menekan tombol pada salah satu soal, terdapat isi konten soal yang ditekan.

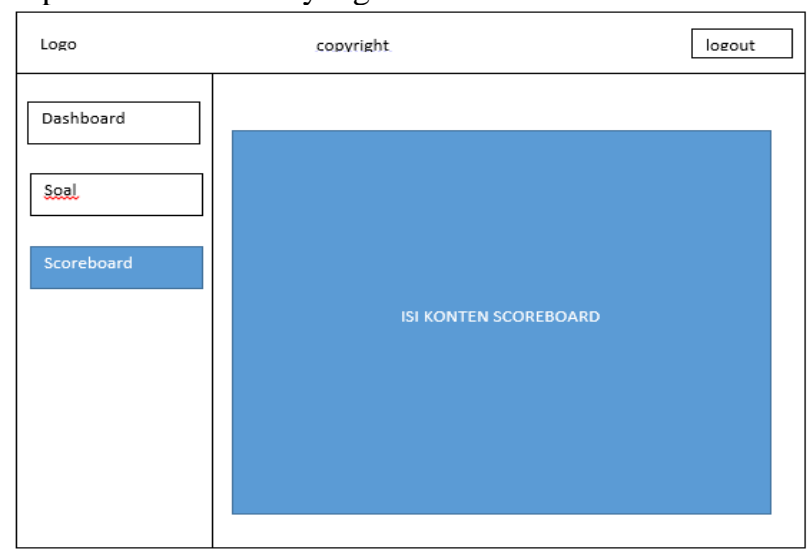

Gambar 14 Tampilan Scoreboard User

Penjelasan dari Gambar 14 yaitu skema pada tampilan scoreboard pada user, yang isinya nilai-nilai \& peringkat pada user lain. 


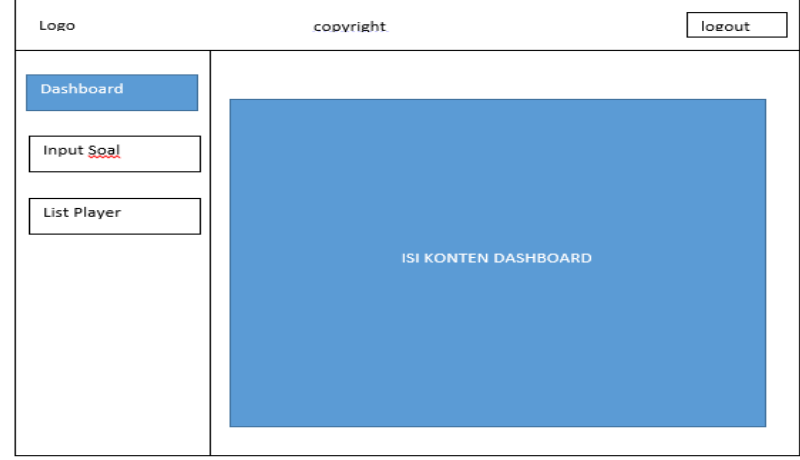

Gambar 15 Tampilan Dashboard Admin

Penjelasan dari Gambar 15 yaitu skema tampilan sistem web pada bagian admin, terdapat logo yang nantinya akan dibuat untuk tombol home. Sedangkan untuk copyright, dibuat label copyright pada web. Terdapat juga tombol logout untuk admin melakukan keluar pada sistem web. Fitur tombol dashboard nanti akan menampilkan konten list soal yang terdapat pada konten dashboard.

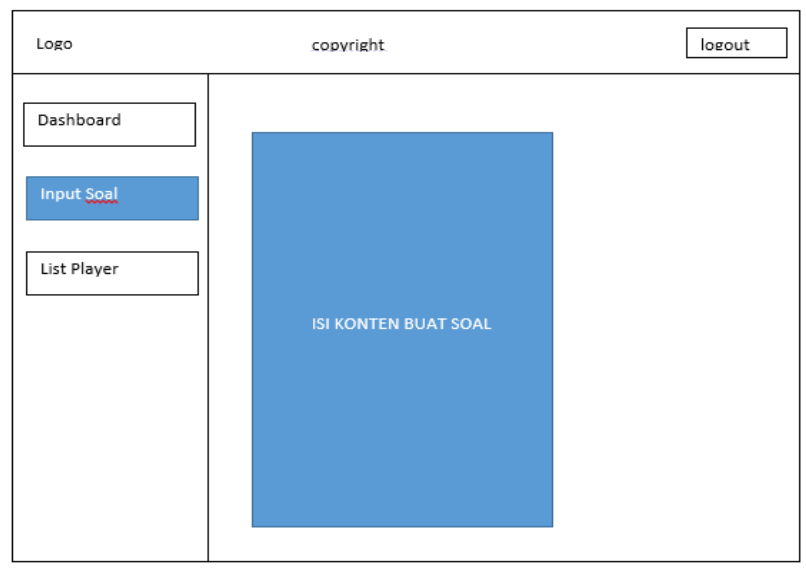

Gambar 16 Tampilan Input Soal Admin

Penjelasan dari Gambar 16 yaitu skema tampilan input soal pada admin, fungsi pada fitur tersebut digunakan admin untuk membuat soal untuk user yang berbentuk form.

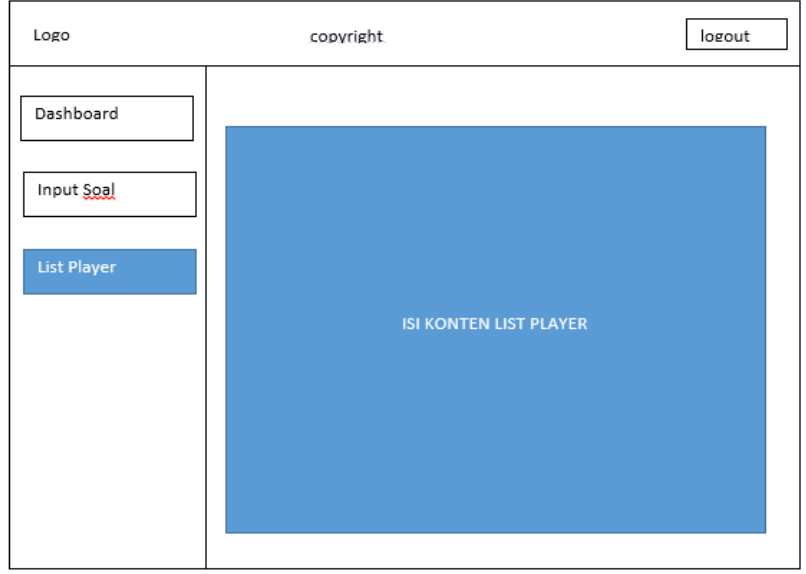

Gambar 17 Tampilan List Player Admin

Penjelasan dari Gambar 17 yaitu skema tampilan input soal pada admin, fungsi pada fitur tersebut digunakan admin untuk mengatur user.

\section{IMPLEMENTASI DAN HASIL}

\section{A. Proses Scanning}

User terlebih dahulu menghidupkan server selanjutnya user melakukan scanning terhadap server target, hasil dari scanning bisa dilihat pada Gambar 18.

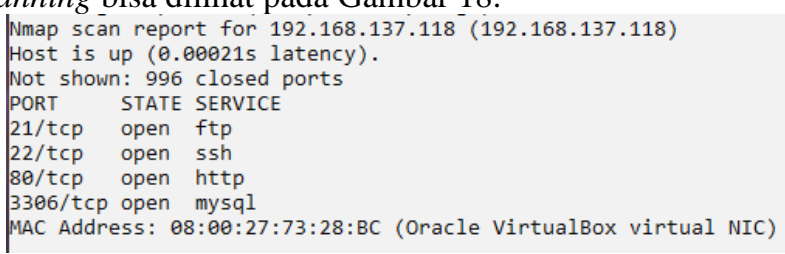

Gambar 18 Proses Scanning

\section{B. Proses Login}

User hanya mengisi inputan email dan inputan password, setelah berhasil melakukan login user akan diarahkan ke halaman dashboard user. Berikut tampilan halaman login pada Gambar 19.

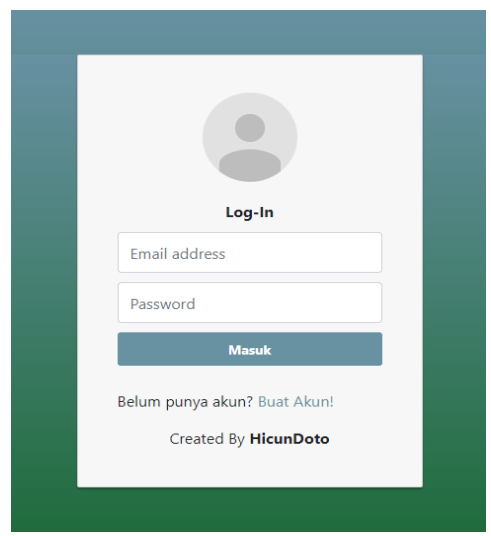

Gambar 19 Tampilan Halaman Login 


\section{Halaman Dashboard User}

Halaman Dashboard User merupakan halaman yang berisi panduan setting virtual machine dan panduan menjawab soal. Pada halaman ini terdapat 3 menu pada menubar yaitu menu Dashboard, Soal, dan Scoreboard. Tampilan dashboard User bisa dilihat pada Gambar 20.

\section{Proses Mengerjakan Soal}

Ketika user akan mengerjakan soal maka user di haruskan memilih menu soal. Setelah itu, akan diarahkan ke halaman soal. Pada halaman soal user akan di suguhkan dengan beberapa soal yang tersedia untuk memilih soal yang ingin dikerjakan dapat menekan tombol "lihat soal" pada soal yang dipilih. Halaman soal bisa di lihat pada Gambar 21.

Setelah menekan tombol "lihat soal" akan menampilkan halaman pop up detail soal yang dipilih, yang isinya terdapat keterangan soal, clue soal, waktu dan inputan flag. Berikut tampilannya pada Gambar 22.

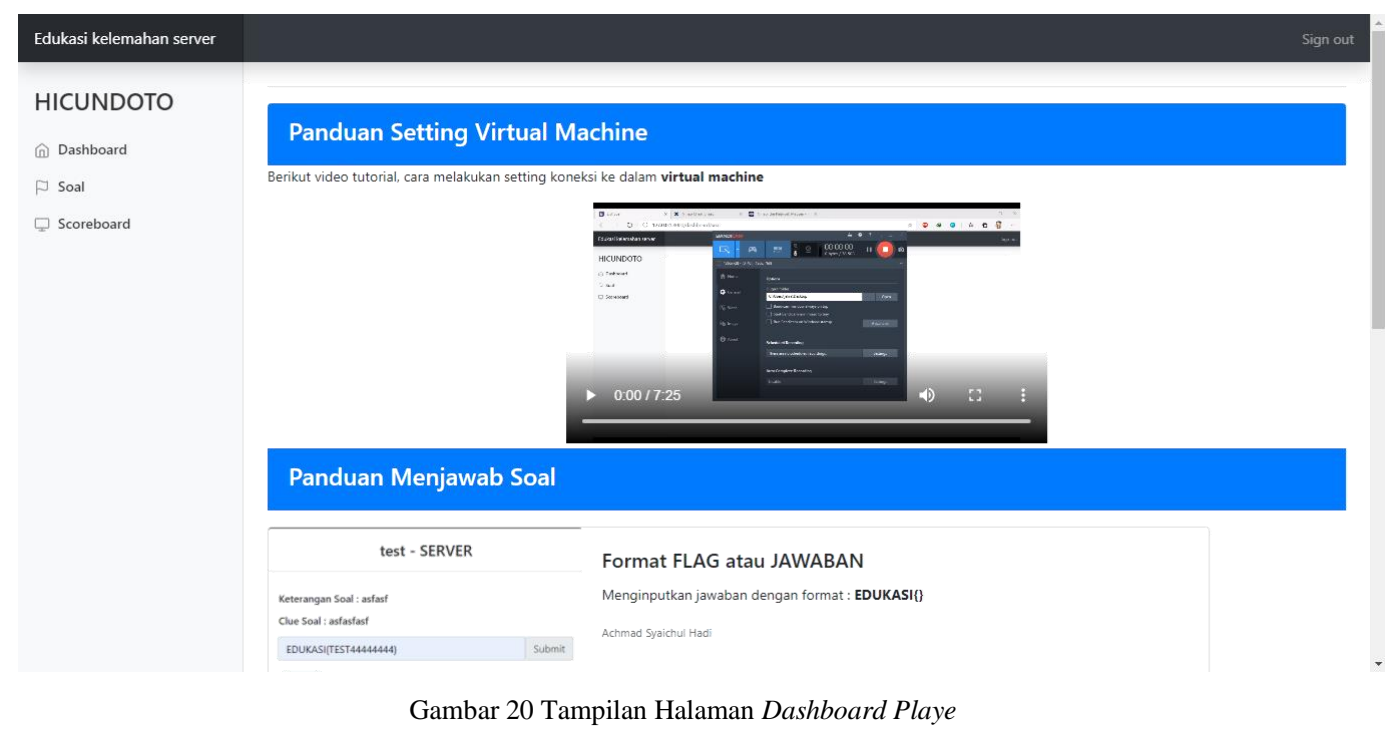

Edukasi kelemahan server

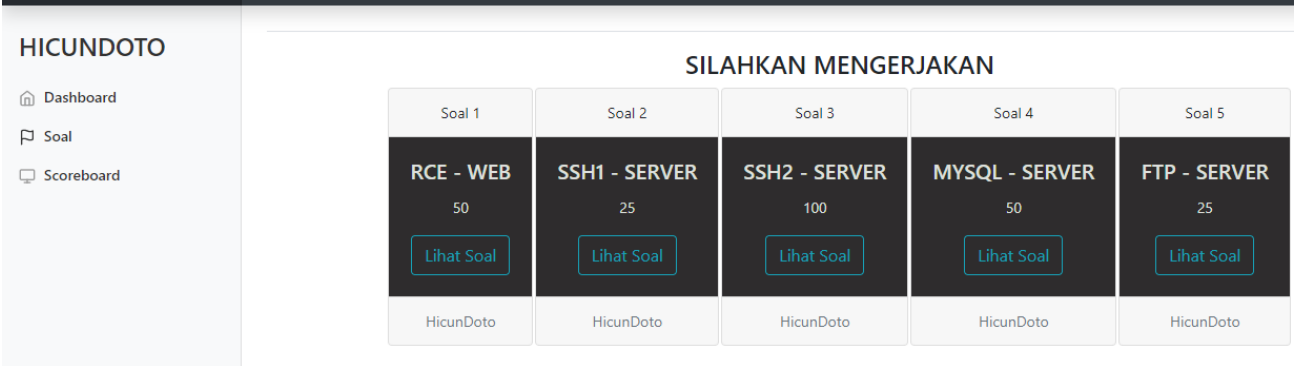

Gambar 21 Tampilan Halaman Soal User

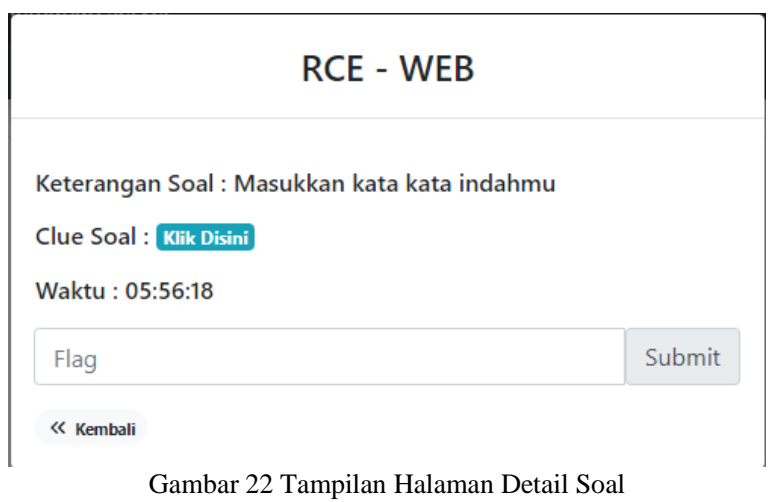

Gambar 22 Tampilan Halaman Detail Soal 
Halaman detail soal terdapat clue soal, yang fungsi nya jika user menemukan kendala saat mengerjakan soal. Berikut tampilannya pada Gambar 23.

User melakukan pencarian jawaban atau flag melalui petunjuk yang tersedia pada halaman clue. Berikut contoh jawaban atau flag pada salah satu soal, bisa dilihat pada Gambar 24.

Setelah user sudah menemukan jawaban atau flag, user dapat melakukan submit flag pada inputan flag di halaman detail soal, berikut tampilan jawaban benar pada Gambar 25.

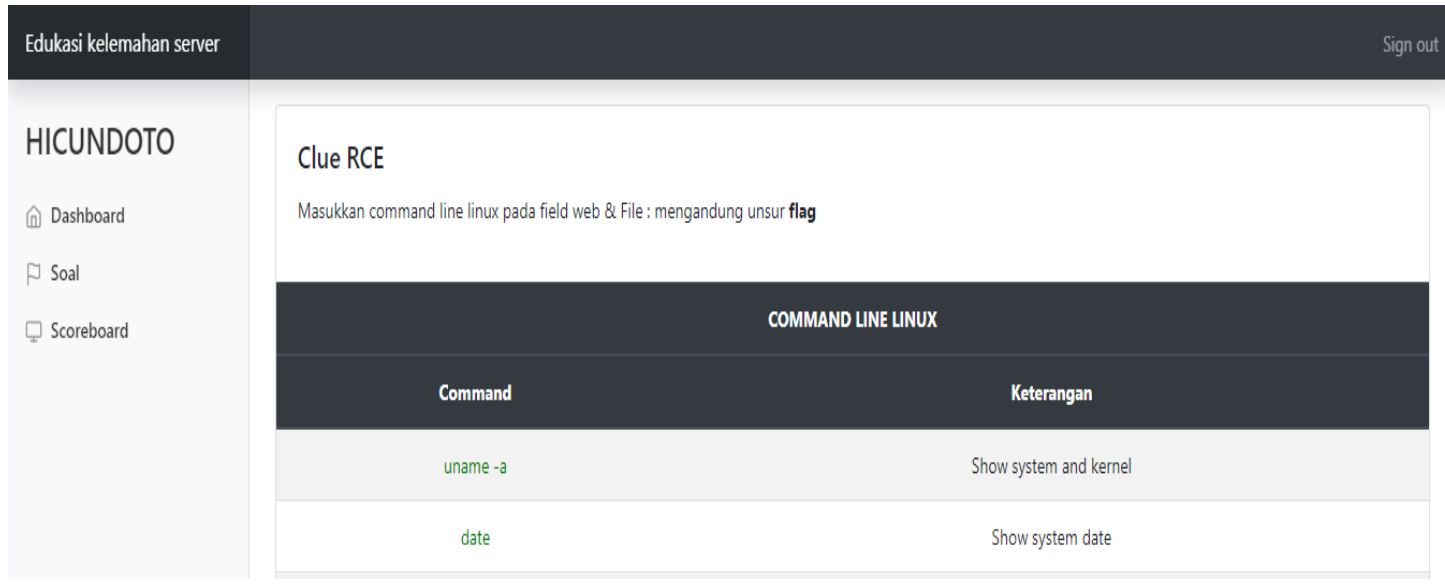

Gambar 23 Tampilan Halaman Clue Soal

Masukkan kata kata

Masukkan disini

ini kata katamu : cat flag.sh

Gambar 24 Tampilan Contoh Jawaban Salah Satu Soal

\begin{tabular}{|l|l|}
\hline \multicolumn{1}{|c|}{ test - SERVER } & \\
\hline Keterangan Soal : asfasf & \\
Clue Soal : asfasfasf & Submit \\
\hline Flag & \\
\hline Flag benar! Link eduknai & \\
\hline « Kembali & \\
\hline
\end{tabular}

Gambar 25 Tampilan Halaman Detail Soal (jawaban benar)

\section{E. Proses Edukasi}

Ketika player selesai menjawab soal dengan benar, maka user bisa melihat edukasi yang berbentuk video pada halaman scoreboard dan menekan pada kolom Link Edukasi. Berikut tampilan link edukasi pada Gambar 26.
Setelah menekan link edukasi, user akan diarahkan ke halaman edukasi yang dimana halaman tersebut, terdapat sebuah video edukasi bagaimana cara menambal atau mengatasi celah pada port service yang tertera pada soal tersebut. Berikut tampilan halaman edukasi pada Gambar 27. 


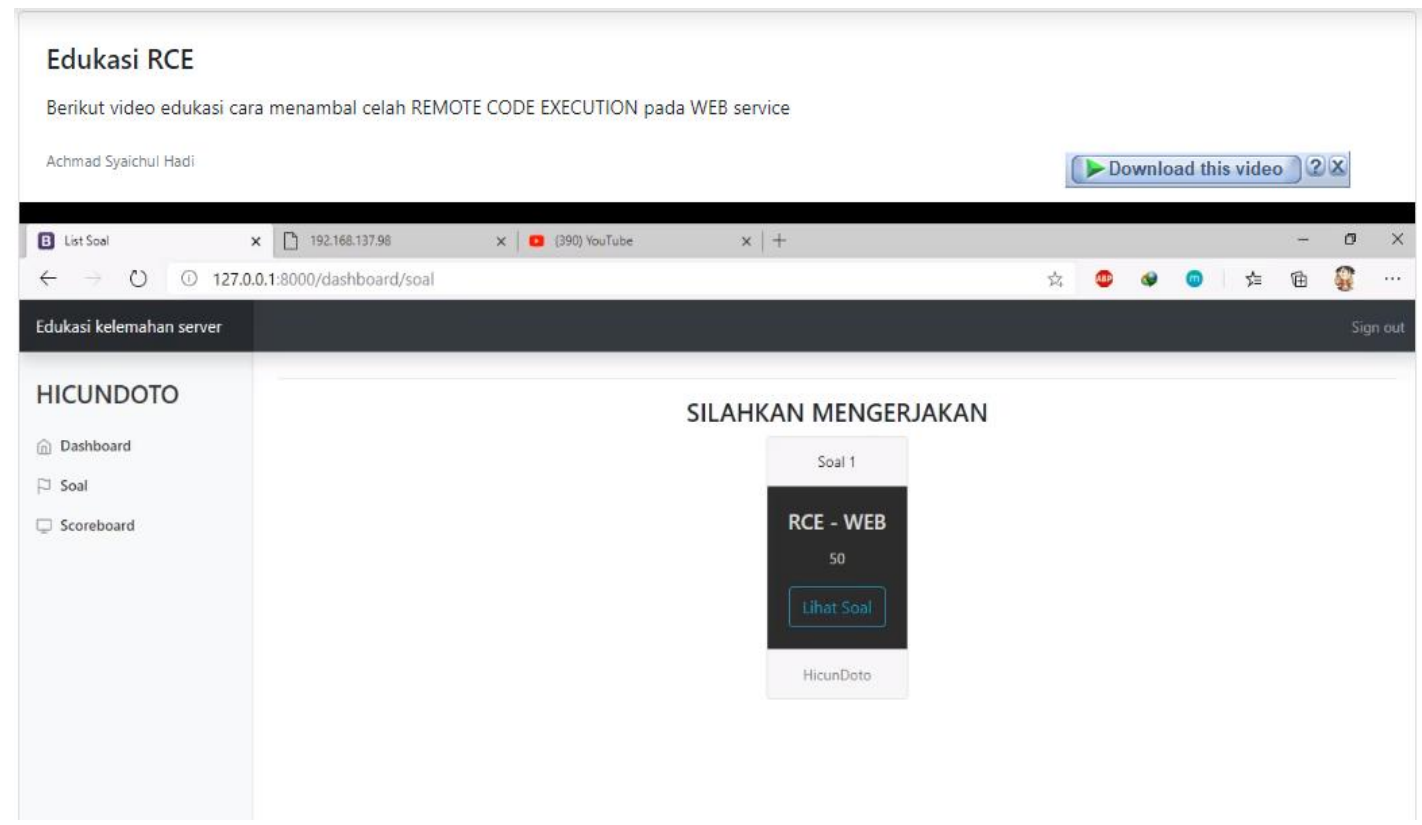

Gambar 27 Tampilan Halaman Edukasi

\section{F. Pengujian Beta}

Pengujian beta merupakan pengujian yang dilakukan secara objektif dimana sistem diuji secara langsung kelapangan yaitu dengan user yang terpilih akan mencoba sistem edukasi server dicoba kepada sebagian user dengan mengambil sampel sebanyak 10 orang, dengan profil mahasiswa dari jurusan teknik informatika, nilai dan profil sampel dapat dilihat pada Tabel IV.

TABEL II

NILAI \& BOBOT PADA SOAL

\begin{tabular}{|c|c|}
\hline Nilai & Bobot \\
\hline 25 & Mudah \\
\hline 50 & Sedang \\
\hline 100 & Sulit \\
\hline
\end{tabular}

Penjelasan Tabel II yaitu mengenai nilai dan bobot soal yang tersedia di setiap soal, nilai 25 memiliki soal dengan bobot mudah dikarenakan soal tersebut memiliki tingkat kesulitan yang mudah, nilai 50 memiliki soal dengan bobot sedang dikarenakan soal tersebut memiliki tingkat kesulitan yang sedang, nilai 100 memiliki soal dengan bobot sulit dikarenakan soal tersebut memiliki tingkat kesulitan yang sulit.

TABEL III

SOAL

\begin{tabular}{|c|c|c|c|c|}
\hline $\begin{array}{c}\text { Nama } \\
\text { Soal }\end{array}$ & Nilai & $\begin{array}{c}\text { User } \\
\text { Berhasil }\end{array}$ & $\begin{array}{c}\text { User } \\
\text { Tidak } \\
\text { Berhasil }\end{array}$ & $\begin{array}{c}\text { Jumlah } \\
\text { Presenta } \\
\text { se }\end{array}$ \\
\hline RCE & 50 & 10 & 0 & $100 \%$ \\
\hline SSH1 & 25 & 10 & 0 & $100 \%$ \\
\hline SSH2 & 100 & 9 & 1 & $90 \%$ \\
\hline MYSQL & 50 & 10 & 0 & $100 \%$ \\
\hline FTP & 25 & 9 & 1 & $90 \%$ \\
\hline
\end{tabular}

Penjelasan Tabel III yaitu mengenai soal yang di sediakan pada sistem, terdapat 5 soal dengan nilai dan bobot yang berbeda. Penjelasan soal dengan kesulitan mudah, user hanya melakukan teknik bruteforce terhadap fitur login dan sudah di sediakan list username dan password pada setiap soal dengan kesulitan mudah, sedangkan soal dengan kesulitan sedang, dimana untuk soal RCE user melakukan teknik analisa pada celah web service, hingga user menggunakan teknik remote code execution pada fitur web tersebut hingga mendapatkan flag, sedangkan soal MYSQL user diberikan list username \& password dipergunakan untuk teknik 
bruteforce, setelah berhasil login, user melakukan teknik analisa pada sisi database disana hingga mendapatkan flag, dan yang terakhir soal dengan kesulitan sulit, dimana soal memiliki kerumitan tingkat tinggi, dimana user harus selesai mengerjakan soal SSH1 terlebih dahulu jika ingin mengerjakan soal SSH2, user melakukan teknik analisa terhadap service tersebut untuk mencari file backup, dimana file backup tersebut sudah terenkripsi dalam bentuk base64, dan dilakukan teknik bruteforce setelah berhasil mendekripsi isi file backup dan melakukan login hingga user mendapatkan flag. Soal yang tidak berhasil terjawab $100 \%$ terdapat pada soal SSH2 dengan bobot sulit dan FTP dengan bobot mudah, yang dimana hanya 1 user yang tidak berhasil menjawab soal tersebut.

TABEL IV

NILAI USER

\begin{tabular}{|c|c|c|c|}
\hline No & Nama User & Profil & Nilai \\
\hline 1 & ACHMAD RIZQI EFENDI & Mahasiswa & 250 \\
\hline 2 & AHMAD SYARIF & Mahasiswa & 250 \\
\hline 3 & $\begin{array}{c}\text { FAIQOTUL HIMMA } \\
\text { RAMADHANTI }\end{array}$ & Mahasiswa & 250 \\
\hline 4 & $\begin{array}{c}\text { FARRELL EGA } \\
\text { SANTOSA }\end{array}$ & Mahasiswa & 250 \\
\hline 5 & KEVIN & Mahasiswa & 250 \\
\hline 6 & $\begin{array}{c}\text { LOLA HERAWATI } \\
\text { MUHAMMAD REZA } \\
\text { PAHLEVI }\end{array}$ & Mahasiswa & 250 \\
\hline 8 & $\begin{array}{c}\text { SEPTIAWAN RIAN } \\
\text { SILVANDO RENGGA } \\
\text { ARNANTA }\end{array}$ & Mahasiswa & 250 \\
\hline 10 & $\begin{array}{c}\text { DWIKI AULIA AKBAR } \\
\text { Mahasiswa }\end{array}$ & 250 \\
\hline
\end{tabular}

Penjelasan Tabel IV yaitu mengenai nilai dan profil user, dimana terdapat 10 orang yang mencoba, dan yang berhasil menjawab semua soal atau nilai sempurna ada 9 orang dan hanya satu orang yang belum bias menjawab semua soal, dapat disimpulkan bahwa soal dan edukasi yang diberikan dapat dipahami oleh user.

\section{SIMPULAN}

Sesuai dengan hasil pengujian pada pengujian beta tersebut bahwa soal RCE, SSH1, MYSQL memiliki 100\% keakuratan user menjawab soal tersebut, sedangkan soal
SSH2 dan FTP memiliki 90\% keakuratan user menjawab soal tersebut. Dapat di simpulkan bahwa sistem edukasi server yang dibangun mudah digunakan, memiliki tampilan responsive dan cukup bagus, serta soal dan edukasi yang diberikan sudah sangat dipahami oleh user.

Pada sistem edukasi server ini masih banyak kekurangan baik dari penulisan, perancangan sistem dan teori yang digunakan. Saran yang dapat di berikan untuk pengembangan yang bisa dilakukan di masa mendatang yaitu menambahkan fitur change profile \& change password, menambahkan celah keamanan server lebih luas, pengembangan aplikasi menjadi aplikasi mobile (andoid \& ios) untuk user agar lebih effisien.

\section{UCAPAN TERIMA KASIH}

Ucapan terima kasih kepada semua pihak Universitas Muhammadiyah Sidoarjo yang sudah memberikan dukungan dalam penelitian ini.

\section{DAFTAR PUSTAKA}

[1] A. Rahmatulloh and F. MSN, "Implementasi Load Balancing Web Server menggunakan Haproxy dan Sinkronisasi File pada Sistem Informasi Akademik Universitas Siliwangi," J. Nas. Teknol. dan Sist. Inf., vol. 3, no. 2, pp. 241-248, 2017, doi: 10.25077/teknosi.v3i2.2017.241-248.

[2] P. Soepomo, “Analisis Dan Perancangan Proxy Server Menggunakan Virtual Machine," J. Sarj. Tek. Inform., vol. 2, no. 3, pp. 1-9, 2014, doi: 10.12928/jstie.v2i3.2643.

[3] I. Syarifudin, "Pentesting dan Analisis Keamanan Web Paud Dikmas," Pentesting Dan Anal. Keamanan Web Paud Dikmas, no. April, 2018, doi: 10.5281/zenodo.1211847.

[4] T. Keerthika, A. Adithyan, S. Balaji, and M. J. Lunia, "Remote Code Execution in Web Applications," Int. J. Eng. Technol., vol. 7, pp. 384-387, 2018.

[5] T. Hidayat, A. Hidayatullah, and R. Agustini, "Kajian Permainan Edukasi dalam Pembelajaran Bahasa Indonesia," Deiksis J. Pendidik. Bhs. dan Sastra Indones., vol. 6, no. 2, p. 59, 2019, doi: 10.33603/dj.v6i2.2111.

[6] A. P. N. Erri Wahyu Puspitarini, Dian Wahyu Putra, "Game Edukasi Berbasis Android Sebagai Media Pembelajaran Untuk Anak Usia Dini," J I M P - J. Inform. Merdeka Pasuruan, vol. 1, no. 1, pp. 46-58, 2016, doi: 10.37438/jimp.v1i1.7.

[7] N. Arkaan and D. V. S. Y. Sakti, "Implementasi Low Interaction Honeypot Untuk Analisa Serangan Pada Protokol SSH," J. Nas. Teknol. dan Sist. Inf., vol. 5, no. 2, pp. 112-120, 2019, doi: 10.25077/teknosi.v5i2.2019.112-120.

[8] Whisnumurti Adhiwibowo, "Kernel-Based Virtual Machine Untuk Virtualisasi Database Sebagai Solusi," J. Transform., vol. 10, no. 2, pp. 89-98, 2013.

[9] G. Canepa, VirtualBox Essentials. Exelixis Media P.C, 2016.

[10] G. Held, Server Management. CRC Press LLC, 2000.

[11] S. Sukaridhoto, "Buku Jaringan Komputer I," 2014, [Online]. Available:

http://dhoto.lecturer.pens.ac.id/publications/book/2014/DhotoJaringanKomputer1.pdf.

[12] A. Muhyidin and U. N. Yogyakarta, Buku Ubuntu Server Fundamental ( Ubuntu Camp 2016), no. April 2016. 2019.

[13] J. Enterprise, Mengenal PHP Menggunakan Framework Laravel. Jakarta: PT Elex Media Komputindo, 2015.

[14] J. Enterprise, Pemrograman Bootstrap Untuk Pemula. PT Elex Media Komputindo, 2016.

[15] A. Solichin, MySQL Dari Pemula Hingga Mahir. 2010 